\title{
Nutritive value and fermentation characteristics of alfalfa-mixed grass forage wrapped with minimal stretch film layers and stored for different lengths of time
}

\author{
W. K. Coblentz, ${ }^{1}$ R. K. Ogden, ${ }^{*}$ M. S. Akins, $†$ and E. A. Chow \\ *USDA-ARS, US Dairy Forage Research Center, Marshfield, WI 54449 \\ †Department of Dairy Science, University of Wisconsin, Madison 53706 \\ ‡Kuraray America Inc., Pasadena, TX 77507
}

\begin{abstract}
A key aspect of managing baled silages is to quickly achieve and then rigorously maintain anaerobic conditions within the silage mass. The concept of inserting an $\mathrm{O}_{2}$-limiting barrier (OB) into plastic commercial silage wraps has been evaluated previously, yielding mixed or inconclusive results. Our objective for this study was to maximize the challenge to a commercial polyethylene bale wrap, or the identical wrap containing an OB, by using minimal plastic (4 layers), and then extending storage periods as long as $357 \mathrm{~d}$. Forty-eight $1.2 \times 1.2-$ $\mathrm{m}$ large-round bales of alfalfa (Medicago sativa L.) and mixed grass forage $(66.3 \pm 8.66 \%$ alfalfa; DM basis $)$ were made at 2 moisture concentrations [ 47.5 (ideal) or $36.1 \%$ (dry)], wrapped with 4 layers of plastic containing an OB or no OB, and then stored for 99, 243, or 357 d. After storage, yeast counts within the 0.15-m deep surface layer were not affected by treatment (mean = $5.85 \log _{10} \mathrm{cfu} / \mathrm{g}$ ); mold counts could not be analyzed statistically because 26 bales were nondetectable at a $3.00 \log _{10} \mathrm{cfu} / \mathrm{g}$ detection limit, but means among detectable counts were numerically similar for OB (4.74 $\left.\log _{10} \mathrm{cfu} / \mathrm{g}\right)$ and no OB $\left(4.77 \log _{10} \mathrm{cfu} / \mathrm{g}\right)$. Fermentation characteristics were most affected by initial bale moisture, resulting in a more acidic final $\mathrm{pH}$ for ideal compared with dry bales (5.52 vs. 6.00). This was facilitated by greater concentrations of total fermentation acids ( 3.80 vs. $1.45 \%$ of dry matter), lactic acid (2.24 vs. $0.71 \%$ of dry matter), and acetic acid (1.07 vs. $0.64 \%$ of dry matter) within ideal compared with dry silages. Plastic wrap type had no effect on final concentrations of any fermentation product. During fermentation and storage, we noted greater change in concentrations of fiber components and whole-plant ash within the
\end{abstract}

Received December 5, 2016.

Accepted March 17, 2017.

${ }^{1}$ Corresponding author: wayne.coblentz@ars.usda.gov 0.15-m deep surface layer than in the bale core, and these changes always differed statistically from 0 (no change) based on pre-ensiled baseline concentrations. Overall, concentrations of water-soluble carbohydrates were reduced (mean $=2.3$ percentage units) during fermentation and storage, which resulted (indirectly) in increased concentrations of fiber components and crude protein, as well as an overall energy cost of 2.2 percentage units of total digestible nutrient. It remains unclear under what conditions an OB plastic wrap will consistently benefit the fermentation and preservation of baled silages.

Key words: alfalfa, baled silage, fermentation, polyethylene layers, nutritive value

\section{INTRODUCTION}

Although the production of baled silages has become increasingly popular, particularly with small- and mid-sized dairy or beef producers, some management considerations differ from those of traditional precisionchopped silages. Recommendations for a target moisture concentration for baled silages (45 to 55\%; Shinners, 2003) are substantially drier than those described commonly for precision-chopped silages, such as alfalfa (Medicago sativa L., $\leq 70 \%$; Muck et al., 2003). One net effect of these differences in recommended moisture concentrations is that fermentation of baled silages is inherently restricted compared with chopped silages, thereby limiting the production of fermentation acids as well as the associated $\mathrm{pH}$ depression within the silage mass (Nicholson et al., 1991). Normally, a low final $\mathrm{pH}$ is considered important because it provides stability to the silage, and ensures that problematic secondary fermentations by clostridia are inhibited. However, this disadvantage in managing baled silages can be offset by decreasing the moisture concentration of the silage, which also exhibits an inhibitory effect on clostridial fermentations (McDonald et al., 1991). Because baled silages are drier, exclusion of oxygen is critically impor- 
tant for preservation. The permeability of plastic films to $\mathrm{O}_{2}$ has the potential to increase aerobic deterioration by stimulating proliferation of aerobic microorganisms, such as yeasts and molds, whose growth also may be stimulated by unfermented sugars that are present in greater concentrations when fermentation is restricted by field wilting (McDonald and Edwards, 1976).

Several studies have evaluated various approaches for limiting oxygen permeability through polyethylene silage wraps. Hancock and Collins (2006) evaluated the number of polyethylene wrapping layers on the subsequent preservation of baled alfalfa silage and determined that more than 2 polyethylene layers are needed for consistent preservation of baled alfalfa; however, little advantage was generally associated with more than 4 layers following a 5-mo storage period. Similarly, Keles et al. (2009) concluded that 2 plastic wrapping layers resulted in inferior preservation, reduced digestibility, extensive mold growth, and deteriorated perennial ryegrass (Lolium perenne L.) baled silage in Ireland. However, these problems were largely remedied by using 4 plastic layers, and little further improvement was observed by increasing plastic usage to 6 layers. In a previous study conducted at our location (Coblentz et al., 2016b), it was concluded that 4 polyethylene layers may ensure acceptable fermentation, but the risk of internal puncture by alfalfa stems during handling or storage may be unacceptable to many producers. Based on visual observations made in that study, 4 polyethylene layers likely represents the practical minimum to obtain an acceptably fermented and preserved baled silage, but additional layers may be desirable to ensure the integrity of the plastic, especially when forages have rigid physical characteristics, such as those of alfalfa stems.

Another approach to limiting oxygen permeability through the polyethylene wrap is to embed an $\mathrm{O}_{2^{-}}$ limiting barrier (OB) within the plastic. Borreani and Tabacco (2008) observed that insertion of an OB within the polyethylene wrap reduced losses of DM during storage, as well as visual estimates of surface mold cover, and may encourage reduced plastic usage, while maintaining good fermentation and storage characteristics. Similar improvements in preservation were found in subsequent studies by the same group (Borreani and Tabacco, 2010) and following meta-analysis of $\mathrm{OB}$ used with a variety of silo types (Wilkinson and Fenlon, 2013). However, other studies have been inconclusive (Coblentz et al., 2016a) or have reported inconsistent improvements of yeast and mold counts at the bale surface compared with no OB (Coblentz et al., 2016b). Our objectives for the current study were to maximize the challenge to a prototype polyethylene bale wrap containing an OB compared with an identical plastic wrap containing no OB (SUN) by using minimal plastic (4 layers) and extended storage periods $(99,243$, or $357 \mathrm{~d})$ that transcended the winter months in central Wisconsin. The integrity of silage plastic wraps was further challenged by making bales within typical recommendations for moisture (47.5\%), but then further wilting to $36.1 \%$ moisture, which is drier than suggested by Shinners (2003).

\section{MATERIALS AND METHODS}

\section{Description of Field Site and Experimental Layout}

A field site planted with Nexgrow 6422Q alfalfa (Forage Genetics International, Nampa, ID) and Alfamaster mixed grasses (Barenbrug USA, Tangent, OR) located on the University of Wisconsin Marshfield Agricultural Research Station $\left(44^{\circ} 39^{\prime} \mathrm{N}, 90^{\circ} 08^{\prime} \mathrm{W}\right)$ was selected for the experiment. The alfalfa/grass mixture was established on May 16, 2013, at respective seeding rates of 5.2 and $3.0 \mathrm{~kg} / \mathrm{ha}$ for the individual alfalfa and mixed grass components of the sward. The alfalfa/mixed grass sward was harvested to a $7.5-\mathrm{cm}$ stubble height with a Case-International Harvester Model 8830 mowerconditioner (J. I. Case Co., Racine, WI) equipped with a sickle-bar cutting mechanism and metal conditioning rollers at $0900 \mathrm{~h}$ on June 30, 2015. The maximum cutting width of the mower-conditioner was $3.7 \mathrm{~m}$, and the mean swath width was $2.41 \pm 0.036 \mathrm{~m}$. At harvest, the alfalfa component of the stand was at the full-flower stage of growth. Prior to baling, a trained technician walked each of 4 field blocks in a zig-zag pattern collecting random grab samples $(\sim 1,300 \mathrm{~g} /$ block; wet basis) to determine percentages of alfalfa and mixed grass within each block, forages were separated by hand, dried to constant weight under forced air at $55^{\circ} \mathrm{C}$, and percentages of alfalfa and mixed grass calculated on a DM basis (66.3 and $33.7 \pm 8.66 \%$, respectively).

Mowed forage was allowed to wilt, undisturbed, until baling began at $1100 \mathrm{~h}$ on July 2 . A total of $481.2 \times$ $1.2-\mathrm{m}$ large-round bales were made for this study; 24 bales ( 6 bales/block) were made at a moisture concentration considered ideal for round-bale silage $(47.5 \%$, ideal), whereas the remaining 24 bales were made at $1530 \mathrm{~h}$ after the moisture concentration was reduced by additional wilting to $36.1 \%$ (dry). A New Holland Roll-Belt 450 round baler (CNH America LLC, Racine, WI) was used to bale all forages in the trial in long-stem form. Each bale was tied upon exit from the bale chamber with 2 revolutions of net wrap. For this research site, there was little obvious reason to suspect topographical variation across field blocks; however, 
the site was blocked to account for possible changes in moisture concentration during baling.

\section{Description of Experimental Treatments}

In addition to moisture concentration (ideal or dry), 2 other treatment factors (polyethylene wrap type and storage time) were evaluated within the treatment structure. Polyethylene wraps included (1) a commercially available bale wrap [Sunfilm (SUN) $750 \mathrm{~mm} \times$ 1,500 m × $25 \mu \mathrm{m}$; AEP Industries Inc., Mt. Top, PA]; and (2) an identical prototype film differing from SUN only by the insertion of an $\mathrm{O}_{2}$-limiting barrier (Kuraray America Inc., Pasadena, TX) within the plastic wrap (OB). The $\mathrm{O}_{2}$ transmission rates for 1 layer of bale wrap measured under conditions of $1 \mathrm{~atm}$ of pressure, $20^{\circ} \mathrm{C}$, and $65 \%$ relative humidity were $198 \mathrm{~cm}^{3} / \mathrm{m}^{2} \cdot \mathrm{d}$ for OB (Kuraray America Inc.) and $6,931 \mathrm{~cm}^{3} / \mathrm{m}^{2} \cdot \mathrm{d}$ for SUN (MOCON Testing Service, Minneapolis, MN). Other physical characteristics of each plastic type (Intertek Plastics Technology Laboratories, Pittsfield, MA) are reported in Table 1. The third treatment factor evaluated was storage time, which was included to maximize the challenge to the integrity of the minimal number of layers (4) of polyethylene wrap. Final sampling of fermented forages was conducted 99 (October 9), 243 (March 2), or $357 \mathrm{~d}$ (June 24) postbaling. Each of the 4 field blocks produced 12 bales, with 1 bale assigned to each of the 12 interactive treatments. Treatment assignments for specific bales were randomized within block such that they were not confounded with baling order.

\section{Initial Bale Processing and Sampling}

Immediately after ejection from the baler, all bales were measured in the field for width and diameter $( \pm 0.2$ $\mathrm{cm})$. Before bales were wrapped, each bale was weighed on a platform scale $( \pm 0.45 \mathrm{~kg})$, and then four $0.61-\mathrm{m}$ deep core samples $(0.025 \mathrm{~m}$ in diameter) were obtained from each bale using a Uni-Forage Sampler (Star Quality Samplers, Edmonton, AB, Canada) fitted to an electric drill. Immediately thereafter, air was purged from the sampling holes with spray-foam insulation, but filling was terminated before insulation spilled over onto the surface of the bale, where it would directly contact the polyethylene wraps. Both types of polyethylene wrap (SUN or OB) were applied with a Model 995 TSR bale wrapper (McHale Engineering Limited; Ballinrobe, Co. Mayo, Ireland) that wraps bales individually. The wrapping system was programed to apply 4 film layers to each bale, which corresponded to 16 revolutions of the table platform. Following wrapping, bales were placed directly on a concrete pad, where they remained, undisturbed, until their final assigned sampling date. The total elapsed time from the initia-

Table 1. Typical physical characteristics of commercial plastic film (SUN), as well as characteristics for the prototype oxygen-barrier (OB) plastic used to wrap 48 alfalfa/mixed grass silage bales at Marshfield, Wisconsin, on July 2, 2015

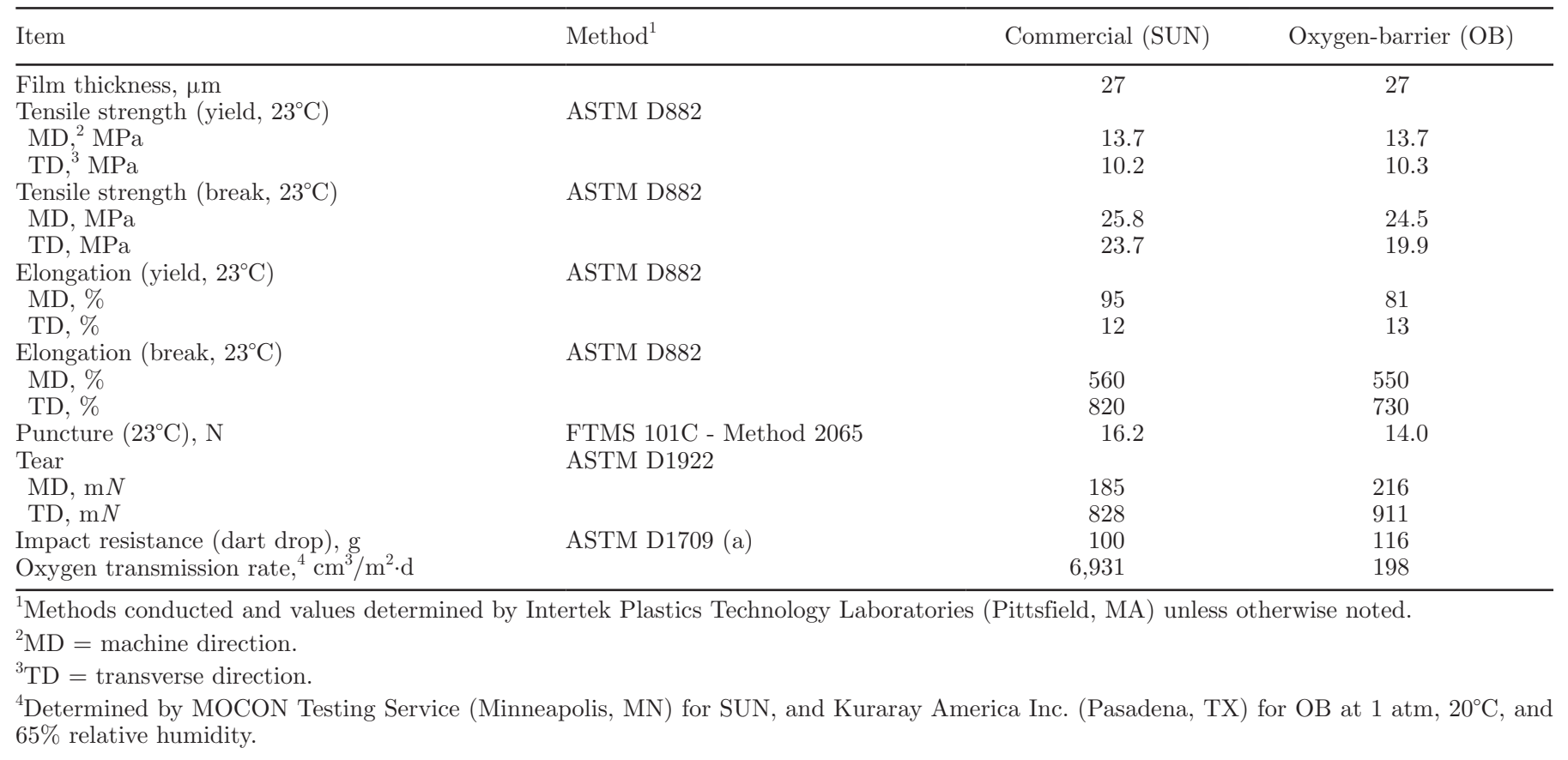


tion of baling at ideal moisture and completion of all wrapping procedures was $7 \mathrm{~h}$ (1145 to $1845 \mathrm{~h}$ ), which is consistent with most good management practices for prompt wrapping of baled silages.

Core samples obtained on a pre-ensiled (before wrapping) basis were composited by bale $(\sim 150 \mathrm{~g} /$ bale; wet basis), sealed in 3.8-L plastic freezer bags, and taken to the research laboratory on ice in insulated coolers. After thorough mixing, a 40-g subsample from each freezer bag was dried overnight at $105^{\circ} \mathrm{C}$ in a convection oven to determine the moisture concentration of each bale. The remaining portion of each composite sample $(\sim 100$ $\mathrm{g})$ was placed in an ultralow freezer $\left(-80^{\circ} \mathrm{C}\right)$, specifically to quickly suspend respiration, and stored there pending all further processing and analysis procedures.

\section{Postensiled Sampling}

On final sampling dates, assigned bales were again weighed on a platform scale as described previously. Each bale was closely inspected for holes in the silage wrap, which were categorized as large $(>7 \mathrm{~mm}$ in diameter) or small $(<7 \mathrm{~mm}$ in diameter). Silage wraps were completely removed from a total of 22 bales and weighed independently to establish a mean correction factor $(2.5 \pm 0.57 \mathrm{~kg})$ for final bale weights. Fermented (postensiled) silage bales were sampled at 2 depths: (1) 0 to $0.15 \mathrm{~m}$ (surface) and (2) 0.15 to $0.61 \mathrm{~m}$ (core). The sampling protocol for these bale depths was similar to that described previously (Coblentz et al., 2016b).

For surface samples, approximately 36 cores $(0.15 \mathrm{~m}$ deep) were taken from 12 rows (3 core samples/row) spaced at intervals of approximately 0.2 to $0.3 \mathrm{~m}$ around the circumferential surface of the bale. The surface cores were composited by bale ( $\sim 400 \mathrm{~g}$; wet basis), placed in sealed freezer bags, and transported to the laboratory on ice in insulated coolers. A 50-g sample was removed immediately from each freezer bag after thorough mixing and dried overnight in a convection oven at $105^{\circ} \mathrm{C}$ to determine the moisture concentration of the surface of each silage bale. The balance of each surface sample ( $\sim 350 \mathrm{~g}$; wet basis) was placed in an ultralow freezer $\left(-80^{\circ} \mathrm{C}\right)$ to suspend respiration, and stored pending further processing and subsequent analysis for nutritive value, $\mathrm{pH}$, silage fermentation products, and yeast and mold counts. The core of each bale was sampled by returning the $0.61-\mathrm{m}$ long sampling probe to the holes created by surface sampling; core samples were obtained by removing silage from depths ranging from 0.15 to $0.61 \mathrm{~m}$ below the bale surface. About 1 core sample per row of surface sampling holes (about 12 cores/bale) produced a similar amount of sample as obtained by surface sampling procedures. The core samples were then assessed for moisture concentration, and the balance of each sample placed in the ultralow freezer to suspend respiration as described previously for surface samples.

\section{Laboratory Analyses}

Pre-Ensiled Forage. The contents of each sealed freezer bag were removed from the ultralow freezer, thoroughly mixed, and a 25-g subsample was removed to determine the initial $\mathrm{pH}$ of each bale. We added $100 \mathrm{~mL}$ of deionized water to each subsample, and the slurry was then macerated for $30 \mathrm{~s}$ in a kitchen blender; following maceration, contents were filtered through 2 layers of cheesecloth and the $\mathrm{pH}$ was read with a bench-top $\mathrm{pH}$ meter. The remaining sample obtained initially from each bale was lyophilized, ground through a 1-mm screen within a Thomas model 4 Wiley mill (Thomas Scientific, Swedesboro, NJ), and then sealed in a plastic sample bag pending subsequent analysis for nutritive value, water-soluble carbohydrates (WSC), and buffering capacity. Concentrations of WSC were determined by extracting 0.25 - $\mathrm{g}$ ground subsamples of each bale in $150 \mathrm{~mL}$ of deionized water for $2 \mathrm{~h}$. The resulting slurry was then filtered (without vacuum) through Whatman \#1 filter paper (GE Healthcare UK Limited, Little Chalfont, Buckinghamshire, UK). The phenol-sulfuric acid reaction (Dubois et al., 1956) was used to quantify WSC, with final concentrations determined colorimetrically using a double-beam spectrophotometer and dextrose to formulate standards. Buffering capacity was determined via titration, and reported as milliequivalents of $\mathrm{HCl}$ per kilogram of forage DM needed to reduce $\mathrm{pH}$ from 6.0 to 4.0 (Muck and Walgenbach, 1985; Coblentz and Muck, 2012).

Postensiled Forage. Fermented silage samples were processed and analyzed for $\mathrm{pH}$ and WSC as described previously. Determination of buffering capacity was omitted for samples obtained on a postensiled basis. Prior to lyophilization and grinding, a 30-g subsample of fermented forage from each bale was sent to Cumberland Valley Analytical Services (Maugansville, MD). Concentrations of fermentation products were determined from extracts obtained following overnight suspension of silage samples in deionized water $(12.5 \%$ wt/vol) and filtering through coarse filter paper. Extracts were evaluated for $\mathrm{NH}_{3}-\mathrm{N}$ (Labconco Rapidstill II model 65200 Analyzer; Labconco, Kansas City, MO), titratable acidity (Mettler DL12 Titrator; Mettler-Toledo, Inc., Columbus, OH), lactic acid (YSI 2700 Select Biochemistry Analyzer; YSI, Inc., Yellow Springs, OH), and other fermentation acids by GC (PerkinElmer AutoSystem; PerkinElmer Inc., Shelton, CN). Yeasts and molds counts from the surface of each bale were quantified by a modification of official method 995.21 
(AOAC International, 2005). Ten grams of silages were weighed aseptically into sterile plastic bags, and subsequently suspended in $90 \mathrm{~mL}$ of sterile peptone solution and shaken by hand for $60 \mathrm{~s}$. The sterile peptone solution was prepared by weighing $1 \mathrm{~g}$ of powdered peptone water (Acumedia Catalog \#7365A; Neogen Corp., Lansing, MI), adding the powder to $1 \mathrm{~L}$ of deionized water, and autoclaving in a glass bottle at $250^{\circ} \mathrm{C}$ for $20 \mathrm{~min}$. Serial dilutions were prepared and plated in quadruplicate on Petrifilm Rapid Yeast and Mold Count Plates (3M Company, St. Paul, MN). Plates were incubated at 20 to $25^{\circ} \mathrm{C}$ for $3 \mathrm{~d}$, and mold and yeast colonies were manually counted using a $2 \times$ magnifying lens (detection limit $=3.0 \log _{10} \mathrm{cfu} / \mathrm{g}$ ). Mold and yeast colonies were differentiated based on typical visual characteristics of each type, such as colony size, color, definition of edges, and so on.

Nutritive Value. Ground forage samples were analyzed for NDF, ADF, hemicellulose (HEMI), cellulose (CELL), and ADL using sequential batch procedures outlined by Ankom Technology Corp. (Macedon, NY) for an Ankom200 Fiber Analyzer. The NDF solution omitted both sodium sulfite and heat-stable $\alpha$-amylase. Concentrations of whole-plant ash were quantified by combusting 1.0-g samples of each forage in a muffle furnace for $6 \mathrm{~h}$ at $500^{\circ} \mathrm{C}$. A rapid combustion procedure (AOAC International, 1998, official method 990.03; model TruMac CN, Leco Corp., St. Joseph, MI) was used to determine total $\mathrm{N}$ within each forage sample, and a factor of 6.25 was used to convert total $\mathrm{N}$ to $\mathrm{CP}$. The total CP pool was further partitioned based on insolubility in neutral- or acid-detergent (NDICP and ADICP, respectively) following nonsequential digestion in each respective solution. As described previously, the NDF solution contained no sodium sulfite or heat-stable $\alpha$-amylase; quantification of $\mathrm{CP}$ within NDF and ADF residues was completed with the identical rapid combustion procedure described previously. The summative approach was used to determine TDN, where the ADL option was used to estimate truly digestible fiber (NRC, 2001; Weiss et al., 1992).

\section{Statistics}

All bale characteristics, pre- and post-ensiled nutritive value, silage fermentation products, and yeast counts were analyzed by PROC MIXED of SAS (version 9.3; SAS Institute Inc., Cary, NC) as a randomized complete block design with 4 field blocks, based on baling order, as replications. A complete $2 \times 2 \times 3$ factorial arrangement of treatments was included within each field block that included 2 bale moisture concentrations (ideal, dry), 2 polyethylene bale wraps (OB, SUN), and 3 final sampling dates. The statistical model was expanded further to include sampling location (surface, core) as a subplot term within the analysis of fermentation products and postensiled nutritive value. Changes in nutritive value occurring during fermentation and storage (i.e., $\triangle \mathrm{NDF}=$ postensiled $\mathrm{NDF}$ - pre-ensiled NDF) were analyzed similarly with sampling location again included in the model as a subplot term. Furthermore, $\Delta$ values were compared with 0 (no change) using the $P>|t|$ value reported for each least squares means in the PROC MIXED analysis. All least squares means were compared with logical contrast statements that included (1) ideal versus dry initial bale moisture; (2) OB versus SUN polyethylene wraps; (3) linear effect of storage time; (4) quadratic effect of storage time; and (5) surface versus core sampling locations (if appropriate). We used PROC IML of SAS to adjust orthogonal coefficients for unequal spacing between final sampling dates. For this study, yeast and mold counts were transformed to a $\log _{10}$ colony-forming units per gram basis before conducting statistical analyses. Analysis of yeast counts was conducted as described previously; however, mold counts for 26 of the 48 total bales were $<3.00$ $\log _{10} \mathrm{cfu} / \mathrm{g}$ of detection limit and could not be analyzed by ANOVA. Statistical significance was declared at $P$ $\leq 0.05$. Throughout this experiment, interactions of main effects were rarely significant at $P \leq 0.05$; on this basis, all data are reported and discussed as main effect means only.

\section{RESULTS AND DISCUSSION}

\section{Pre-Ensiled Bale Characteristics}

On a pre-ensiled basis, initial bale characteristics differed primarily between ideal and dry initial bale moistures (data not shown). As expected, ideal bales exhibited greater wet weight (500 vs. $420 \mathrm{~kg} ; P<0.001$ ), and a greater moisture concentration $(47.5$ vs. $36.1 \% ; P<$ $0.001)$ than dry bales. The initial bale moisture for ideal bales was within the recommended range (45 to 55\%) suggested by Shinners (2003) for baled silages. Overall, the mean DM density for all bales in this experiment was $155 \mathrm{~kg}$ of $\mathrm{DM} / \mathrm{m}^{3}$, which is slightly less than the recommended target density of $162 \mathrm{~kg}$ of $\mathrm{DM} / \mathrm{m}^{3}(10$ lbs of DM $/ \mathrm{ft}^{3}$ ) suggested by Jennings (2011); partially, this resulted from a procedural compromise, in which an aggressive baler ground speed was maintained to minimize baling time, thereby avoiding or limiting the creation of unnecessary moisture gradients across field blocks. Initial buffering capacity (mean $=420 \mathrm{mEq}$ / $\mathrm{kg}$ of $\mathrm{DM} ; P=0.468)$ and $\mathrm{pH}$ (mean $=6.71 ; P=$ 0.139 ) were not affected by initial bale moisture, but 
concentrations of WSC declined slightly (6.7 vs. $6.6 \%$; $P=0.041)$ with the additional wilting time required to create dry bales.

\section{Postensiled Bale Characteristics}

On a postensiled basis, final wet weights for ideal bales were greater than dry bales (502 vs. $423 \mathrm{~kg} ; P$ $<0.001$ ), as were the respective moisture concentrations at the surface $(50.3$ vs. $37.1 \% ; P<0.001)$ and core (48.6 vs. $37.4 \% ; P<0.001)$ sampling locations (data not shown). In contrast, final dry bale weights were greater for dry compared with ideal bales (265 vs. $254 \mathrm{~kg}$ of $\mathrm{DM} ; P=0.001$ ), and increased linearly $(P<0.001)$ with storage time. Reasons for the latter response remain unclear, although the overall recovery of DM $(98.2 \pm 6.93 \%)$ indicates excellent preservation of forage across all treatments. Although neither the number of small $(<7 \mathrm{~mm})$ or large $(>7 \mathrm{~mm})$ holes in the polyethylene wraps differed on the basis of initial moisture concentration $(P \geq 0.096)$, the total number of holes was greater for dry forages (2.8 vs. 1.6 holes/ bale; $P=0.027)$. In addition, bales wrapped with OB exhibited greater numbers of large (1.0 vs. $0.2 ; P=$ 0.004 ) and total (2.9 vs. $1.4 ; P=0.006$ ) holes per bale compared with SUN bales. Relatively few studies have evaluated the integrity of OB compared with commercial silage plastic wraps. Borreani and Tabacco (2008) counted the number of holes in an $\mathrm{O}_{2}$-barrier stretch film compared with polyethylene film when alfalfa forage was wrapped with 2, 4, 6, or 8 layers of wrap and stored indoors for $273 \mathrm{~d}$. The number of holes declined in an inverse relationship with the number of layers, but this response could not be related to wrap type. Puncturing of plastic wraps has been attributed to stiff alfalfa stems (Borreani and Tabacco, 2008; Coblentz et al., 2016b), especially along the joining edges of the flat ends and circumferential surfaces of the bale (Coblentz et al., 2016b).

\section{Yeast and Mold Counts}

We found detectable counts $\left(\geq 3.00 \log _{10} \mathrm{cfu} / \mathrm{g}\right)$ of yeasts in surface samples of 47 of 48 experimental bales, thereby permitting traditional ANOVA procedures (data not shown). However, no detectable contrasts were found to indicate differences between initial bale moistures $(P=0.217)$, wrap types $(P=0.592)$, or linear $(P=0.776)$ and quadratic $(P=0.072)$ trends related to sampling date. Overall, the mean count for yeasts was $5.85 \log _{10} \mathrm{cfu} / \mathrm{g}$ in the surface layer, which is somewhat greater than reported in previous studies with $\mathrm{O}_{2^{-}}$ barrier wraps or numbers of wrapping layers (Keller et al., 1998; Borreani and Tabacco, 2008; Coblentz et al., 2016b), but is comparable to those reported by Müller et al. (2007) for mixed-grass baled silages sampled after 2 or 14 mo. Keller et al. (1998) recommended 6 or more layers of plastic wrap to improve sealing and reduce gas exchange with the bale's surroundings based on strong reductions of yeast and mold counts in comparisons of 4 wrapping layers with either 6 or 8 layers. Hancock and Collins (2006) suggested that 2 layers of plastic wrap were inadequate based on elevated concentrations of fiber components compared with 4 or 6 layers, but counts of yeasts and molds were not reported. It also should be noted that other studies evaluating numbers of wrapping layers were limited to about $150 \mathrm{~d}$ of outside storage (Keller et al., 1998; Hancock and Collins, 2006) or used inside storage (Borreani and Tabacco, 2008), both of which may have limited the opportunities for air exchange through the plastic wrap compared with the present study. Detectable mold counts were obtained from surface samples within 22 of 48 bales, which prohibits a traditional ANOVA. However, based on the distribution and magnitude of detectable counts (mean $=4.71 \log _{10} \mathrm{cfu} / \mathrm{g}$ ), we did not have adequate information to suggest differences in response to any aspect of the treatment structure. Perhaps the most notable observation were the 15 detectable mold counts for dry (mean $\left.=4.85 \log _{10} \mathrm{cfu} / \mathrm{g}\right)$ compared with only 7 for ideal (mean $=4.56 \log _{10} \mathrm{cfu} / \mathrm{g}$ ) bales, but differences in the magnitude of these counts were not distinctive.

\section{Silage Fermentation Characteristics}

Throughout our study, the primary factor influencing silage fermentation characteristics was initial bale moisture (Table 2). Final $\mathrm{pH}$ for ideal bales was more acidic than observed for dry bales (5.52 vs. $6.00 ; P<$ 0.001 ), which can be linked to the greater production of fermentation acids within ideal bales. Total fermentation acids were 2.6 times greater for ideal compared with dry bales (3.80 vs. $1.45 \%$ of DM; $P<0.001)$. Lactic acid, which is considered to be the most desirable fermentation acid because it acts to discourage the activities of clostridia and enterobacteria (McDonald et al., 1991), was 3.2 times greater in ideal bales (2.24 vs. $0.71 \%$ of DM; $P<0.001)$ compared with dry, accounting for $59.8 \%$ of all fermentation acids. By comparison, lactic acid accounted for only $47.2 \%$ of all fermentation acids in dry baled silages, indicating a reduction in both concentration, as well as the proportion of total acids comprised by lactic acid compared with ideal bales. Production of acetic ( 1.07 vs. $0.64 \%$ of DM; $P$ $<0.001$ ), butyric (0.29 vs. $0.04 \%$ of DM; $P=0.001$ ), propionic $(0.12$ vs. $0.04 ; P<0.001)$, and isobutyric (0.08 vs. $0.01 \% ; P=0.001$ ) acids also were greater for ideal baled silages. Previous work with baled silages has 
demonstrated strong reductions of fermentation acids when initial bale moisture is reduced (Nicholson et al., 1991; Huhnke et al., 1997; Müller et al., 2007; Shinners et al., 2009), and the near absence of lactic acid when alfalfa forage was ensiled as large square bales at $<45 \%$ moisture (Coblentz et al., 2014). Other studies with alfalfa, or mostly alfalfa, baled silages (Shinners et al., 2009; Coblentz et al., 2016b) have reported low or trace concentrations of lactic acid in bales packaged at initial moisture concentrations as dry as $31 \%$.

Within the present study, wrap type and sampling date exhibited only minimal effects on fermentation characteristics. We found no differences $(P \geq 0.209)$ between the OB and SUN wrap types for any silage fermentation characteristic. Sampling date yielded only 3 detectable contrasts: $(1)$ a positive linear effect $(P=$ 0.024 ) on concentrations of $\mathrm{NH}_{3}-\mathrm{N}$ (\% of DM); (2) a quadratic effect $(P=0.025)$ on final silage $\mathrm{pH}$; and (3) a quadratic effect $(P=0.025)$ on final concentrations of acetic acid. Other tests of linear and quadratic effects of sampling date did not demonstrate significance $(P$ $\geq 0.087$ ). Although the effects of storage time were neither consistent, nor definitive, across fermentation products, a previous study with wrapped $0.80 \times 0.48$ $\times 0.36 \mathrm{~m}$ small square bales of mixed grasses (Müller et al., 2007) demonstrated increased lactic and acetic acids between 2 and 14 mo, as well as a continued $\mathrm{pH}$ decline during this time interval.

Lastly, sampling locations (surface or core) differed for several fermentation characteristics, with the core sampling location exhibiting greater concentrations of $\mathrm{NH}_{3}-\mathrm{N}$ (11.8 vs. $11.0 \%$ of total $\left.\mathrm{N} ; P=0.023\right)$ and isobutyric acid (0.07 vs. $0.02 \%$ of DM; $P=0.011$ ). In contrast, the surface sampling location had greater concentrations of acetic (0.97 vs. $0.74 \%$ of DM; $P<$ 0.001 ) and propionic acids (0.09 vs. $0.07 \%$ of DM; $P=$ $0.033)$. Although acetic, propionic, and isobutyric acids differed across sampling locations, their concentrations were within acceptable targets proposed by Mahanna and Chase (2003) and Kung and Shaver (2001).

\section{Nutritive Value}

Pre-Ensiled. Most contrasts comparing measures of nutritive value on a pre-ensiled basis were not significant $(P>0.05$; data not shown), and to maintain a concise presentation of results, all measures of preensiled nutritive value have been summarized as overall experimental means, and are presented in that manner throughout Tables 3 and 4 . Overall pre-ensiled concentrations of NDF (55.7\% of DM), CP (15.1\% of DM), as well as summative estimates of TDN ( $55.7 \%$ of DM) are comparable to respective tabular values reported by
NRC (2001) for mature, mixed grass and legume silage (57.4, 17.4, and $53.6 \%$ of DM).

Postensiled. Generally, changes in concentrations of fiber components during silage fermentation and storage are viewed as potentially a net positive or negative, depending on competing processes of respiration of NSC against hydrolysis of structural carbohydrates during fermentation (Rotz and Muck, 1994). In the present study, we found limited detectable effects of initial bale moisture or wrap type on concentrations of fiber components or whole-plant ash (Table 3). Final concentrations of NDF were greater for dry compared with ideal bales ( 59.9 vs. $58.5 \%$ of DM; $P=0.003$ ), as was $\triangle \mathrm{NDF}$ (4.3 vs. 2.8 percentage units; $P=0.021$ ). Similar responses were observed for HEMI (19.7 vs. $18.3 \%$ of DM; $P<0.001)$ and $\triangle$ HEMI $(2.1$ vs. 1.1 percentage units; $P=0.001$ ). All other comparisons between ideal and dry bales for fiber components did not approach significance $(P \geq 0.324)$. For whole-plant ash, ideal and dry bales differed (8.7 vs. $8.5 \%$ of DM; $P=0.004$ ), but the magnitude of this difference was small and of questionable practical relevance. Comparisons of wrap types differed only for $\triangle \mathrm{NDF}(4.2$ vs 2.9 percentage units; $P=0.050$ ), with the greater change occurring for $\mathrm{OB}$. No other comparison of $\mathrm{OB}$ and SUN for fiber components or ash was significant $(P$ $\geq 0.072$ ). Although we noted relatively few detectable contrasts evaluating responses to initial bale moisture and wrap type, net changes from pre-ensiled concentrations with respect to these treatment effects for all fiber-related means and whole-plant ash differed from 0 (no change) at a minimum of $P \leq 0.05$. Final sampling date yielded linear $(P \leq 0.024)$ effects for NDF, ADF, $\triangle \mathrm{ADF}, \mathrm{HEMI}, \triangle \mathrm{HEMI}, \mathrm{CELL}, \triangle \mathrm{CELL}, \mathrm{ADL}$, and $\triangle \mathrm{ADL}$, in which all measures of nutritive value decreased as storage time was extended, except for HEMI and $\triangle$ HEMI. Generally, these responses are consistent with modest respiratory loss (Rotz and Muck, 1994; Bolsen, 1995), which occurred after applying plastic wrap as trapped oxygen was respired from the forage mass, or from some permeability of silage plastics to air during extended storage. No quadratic responses $(P \geq$ 0.064 ) were observed over final sampling dates for any measure of fiber or ash, except for ADL $(P=0.001)$.

Unlike other treatment factors, we observed very consistent responses for comparisons of sampling locations across measures of fiber components and ash, as well as their $\Delta$-values. In each case, concentrations were greater $(P \leq 0.049)$ at the surface compared with the core, and changes from initial, pre-ensiled concentrations were similarly greater $(P \leq 0.049)$ based on sampling location. In addition, all $\Delta$ values were positive, and differed from 0 at $P<0.01$. These responses 


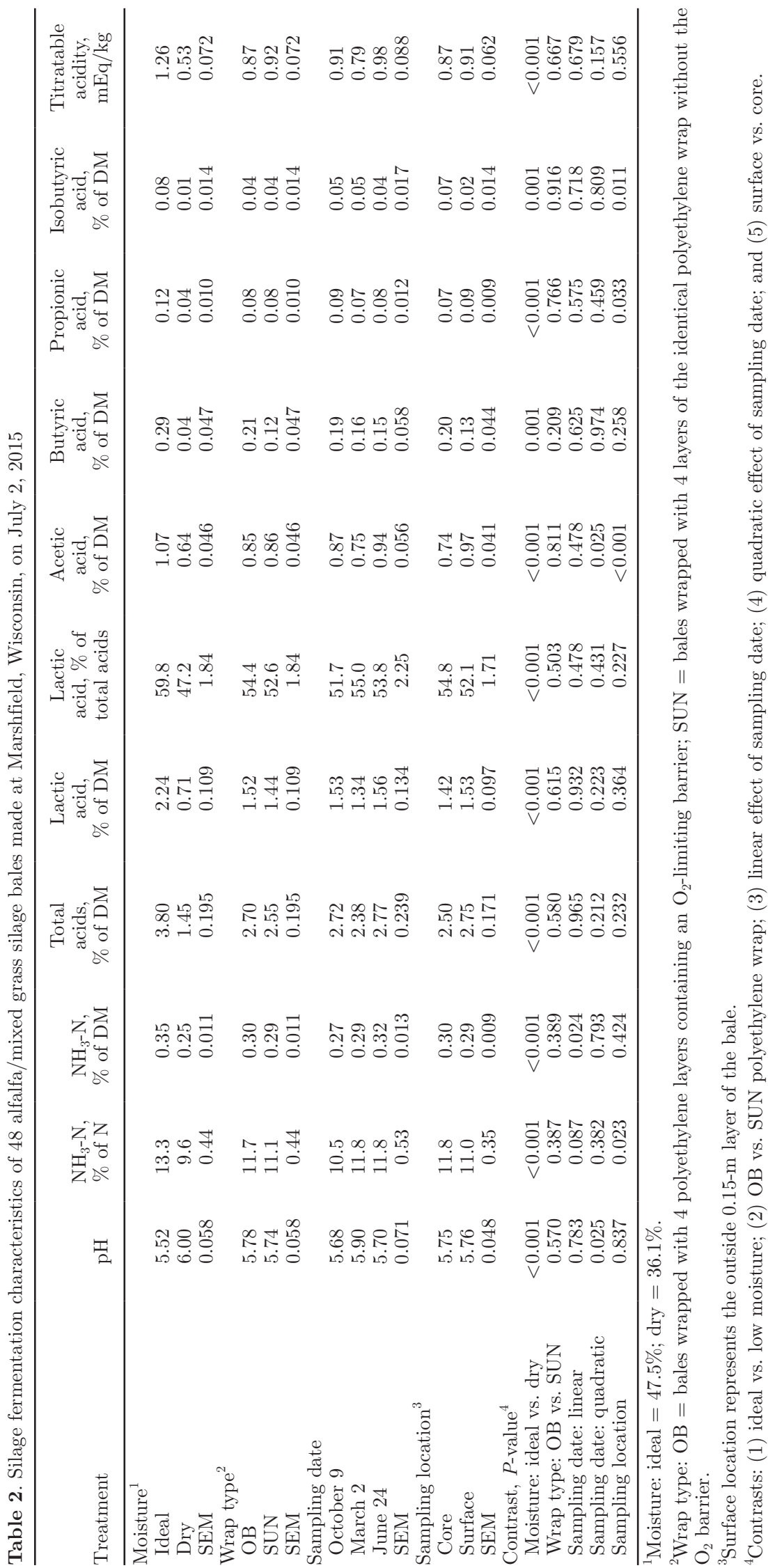


STORAGE LENGTH AND OXYGEN BARRIER FOR BALED SILAGE

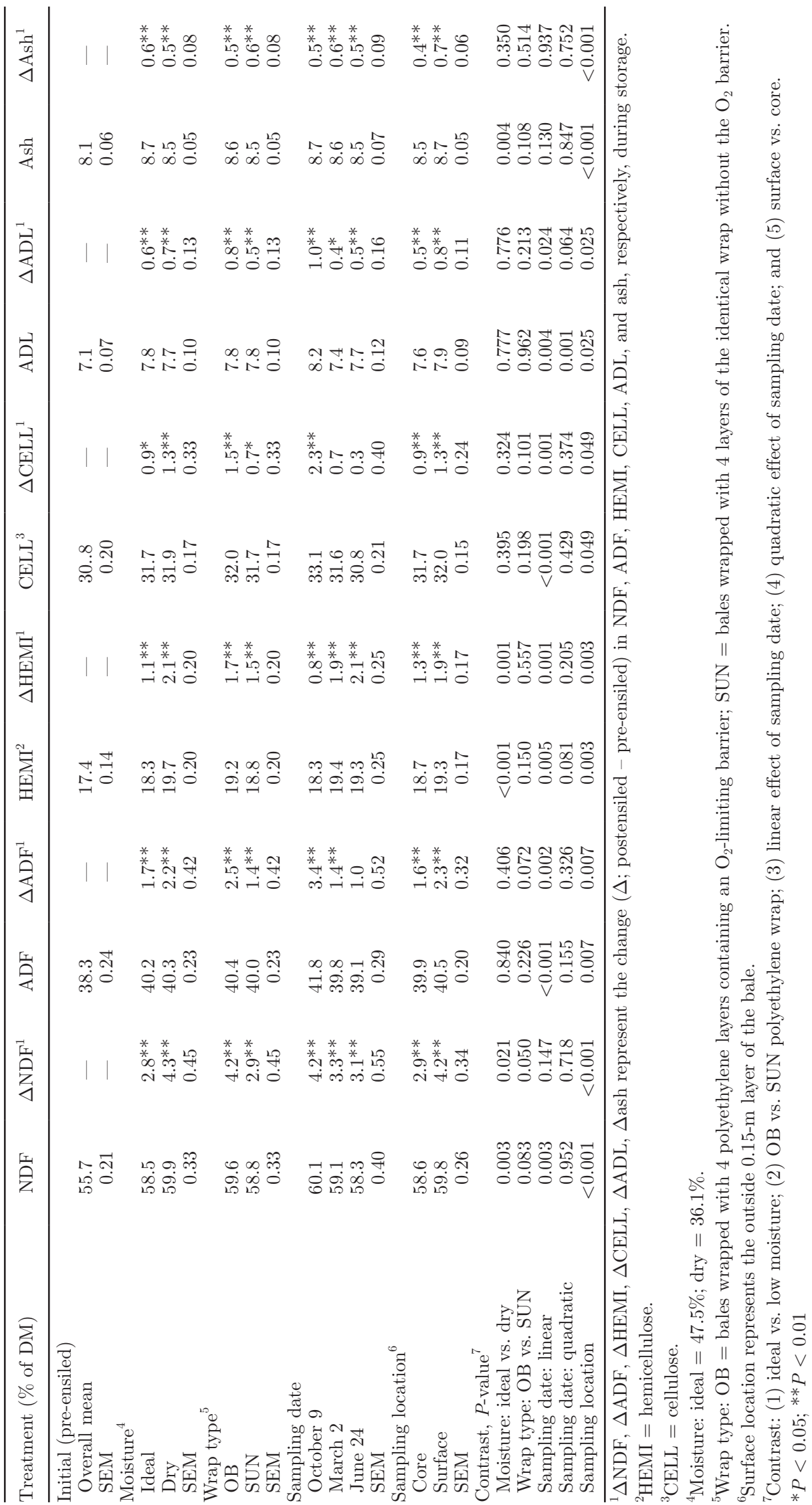


Table 4. Final concentrations of water-soluble carbohydrates, CP components, and TDN for 48 alfalfa/mixed grass silage bales made at Marshfield, Wisconsin, on July 2, 2015

\begin{tabular}{|c|c|c|c|c|c|c|c|c|c|c|}
\hline Treatment ( $\%$ of DM) & $\mathrm{WSC}^{1}$ & $\Delta \mathrm{WSC}^{2}$ & $\mathrm{CP}$ & $\Delta \mathrm{CP}^{2}$ & NDICP ${ }^{3}$ & $\Delta \mathrm{NDICP}^{2}$ & $\mathrm{ADICP}^{4}$ & $\Delta \mathrm{ADICP}^{2}$ & TDN & $\Delta \mathrm{TDN}^{2}$ \\
\hline \multicolumn{11}{|l|}{ Initial (pre-ensiled) } \\
\hline Overall mean & 6.7 & - & 15.1 & - & 3.91 & - & 1.63 & - & 55.7 & - \\
\hline Ideal & 4.3 & $-2.4^{* *}$ & 16.4 & $1.2^{* *}$ & 3.36 & $-0.55^{* *}$ & 1.61 & -0.07 & 53.6 & $-2.0^{* *}$ \\
\hline Dry & 4.5 & $-2.1^{* *}$ & 16.0 & $1.1^{* *}$ & 4.27 & $0.35^{*}$ & 1.66 & 0.08 & 53.6 & $-2.3^{* *}$ \\
\hline SEM & 0.20 & 0.21 & 0.14 & 0.13 & 0.085 & 0.132 & 0.033 & 0.051 & 0.23 & 0.29 \\
\hline SUN & 4.6 & $-2.0^{* *}$ & 16.3 & $1.3^{* *}$ & 3.78 & -0.10 & 1.63 & 0.04 & 53.8 & $-1.9^{* *}$ \\
\hline SEM & 0.20 & 0.21 & 0.14 & 0.13 & 0.085 & 0.132 & 0.033 & 0.051 & 0.23 & 0.29 \\
\hline \multicolumn{11}{|l|}{ Sampling date } \\
\hline October 9 & 5.1 & $-1.4^{* *}$ & 16.3 & $1.3^{* *}$ & 3.79 & -0.04 & 1.61 & -0.04 & 52.7 & $-2.8^{* *}$ \\
\hline March 2 & 4.4 & $-2.2^{* *}$ & 15.5 & $0.6^{* *}$ & 3.53 & $-0.41 *$ & 1.61 & -0.02 & 54.0 & $-1.8^{* *}$ \\
\hline June 24 & 3.7 & $-3.0^{* *}$ & 16.8 & $1.6^{* *}$ & 4.12 & 0.16 & 1.68 & 0.06 & 54.0 & $-1.8^{* *}$ \\
\hline SEM & 0.25 & 0.26 & 0.18 & 0.16 & 0.105 & 0.162 & 0.040 & 0.062 & 0.28 & 0.36 \\
\hline Moisture: ideal vs. dry & 0.412 & 0.250 & 0.085 & 0.750 & $<0.001$ & $<0.001$ & 0.328 & 0.048 & 0.893 & 0.403 \\
\hline Wrap type: OB vs. SUN & 0.166 & 0.105 & 0.578 & 0.152 & 0.588 & 0.952 & 0.792 & 0.360 & 0.295 & 0.169 \\
\hline Sampling date: linear & $<0.001$ & $<0.001$ & 0.069 & 0.258 & 0.054 & 0.488 & 0.228 & 0.272 & 0.001 & 0.040 \\
\hline Sampling date: quadratic & 0.760 & 0.762 & $<0.001$ & $<0.001$ & 0.002 & 0.022 & 0.366 & 0.654 & 0.098 & 0.324 \\
\hline Sampling location & $<0.001$ & $<0.001$ & 0.865 & 0.865 & $<0.001$ & $<0.001$ & 0.006 & 0.006 & $<0.001$ & $<0.001$ \\
\hline
\end{tabular}

${ }^{1} \mathrm{WSC}=$ water-soluble carbohydrates.

${ }^{2} \Delta$ WSC, $\Delta \mathrm{CP}, \triangle \mathrm{NDICP}, \triangle \mathrm{ADICP}$, and $\Delta \mathrm{TDN}$ represent the change ( $\Delta$; postensiled - pre-ensiled) in WSC, CP, NDICP, ADICP, and TDN, respectively, during storage.

${ }^{3} \mathrm{NDICP}=$ neutral-detergent insoluble CP.

${ }^{4} \mathrm{ADICP}=$ acid-detergent insoluble $\mathrm{CP}$.

${ }^{5}$ Moisture: ideal $=47.5 \%$; dry $=36.1 \%$.

${ }^{6}$ Wrap type: $\mathrm{OB}=$ bales wrapped with 4 polyethylene layers containing an $\mathrm{O}_{2}$-limiting barrier; $\mathrm{SUN}=$ bales wrapped with 4 layers of the identical polyethylene wrap without the $\mathrm{O}_{2}$ barrier.

${ }^{7}$ Surface location represents the outside 0.15 -m layer of the bale.

${ }^{8}$ Contrast: (1) ideal vs. low moisture; (2) OB vs. SUN polyethylene wrap; (3) linear effect of sampling date; (4) quadratic effect of sampling date; and (5) surface vs. core.

${ }^{*} P<0.05 ; * * P<0.01$

are consistent with slightly greater DM loss at the bale surface, likely occurring via respiratory activity facilitated by some permeability of plastics to oxygen, and closer proximity to air for surface compared with core samples.

Final concentrations of WSC (Table 4) were not affected by initial bale moisture (mean $=4.4$ of DM; $P=0.412)$ or wrap type $(P=0.166)$, but declined linearly $(P<0.001)$ from 5.1 to $3.7 \%$ across sampling dates that extended to $357 \mathrm{~d}$ postbaling. In addition, residual (postensiled) WSC were greater for core compared with surface (4.8 vs. $4.0 \%$ of DM; $P<0.001$ ). All $\triangle \mathrm{WSC}$ values were negative, indicating a net loss relative to pre-ensiled concentrations, and differed from 0 (no change) at $P<0.01$. The overall net loss of WSC is consistent with expectations for fermented forages, in which WSC serve as the primary substrate for silage fermentation (McDonald et al., 1991). However, pre-ensiled field wilting also restricts fermentation, thereby resulting in greater concentrations of residual WSC than often remains after fermenting wet forages (McDonald and Edwards, 1976). Our study included significant field-wilting, and the mean residual WSC never fell below $3.7 \%$ of DM, which occurred on the final sampling date (June 24).

Statistical analysis of CP, NDICP, and ADICP (Table 4) yielded somewhat erratic responses to treatment. Concentrations of $\mathrm{CP}$ exhibited a quadratic response $(P<0.001)$ to sampling date, but no other contrast was significant $(P \geq 0.069)$. Generally, fermentation and storage resulted in consistently positive $\Delta \mathrm{CP}$ values (mean $=1.2$ percentage units), and means associated with all treatment factors differed from 0 at $P<0.01$. Much as observed for fiber components, the consistently positive nature of $\Delta \mathrm{CP}$ values was an indirect consequence of respiration, in which NSC are lost 
but CP is not, especially in the absence of effluent production or when silage crops do not have problematic nitrate accumulations (Rotz and Muck, 1994). Concentrations of NDICP were greater for dry compared with ideal bales $(4.27$ vs. $3.36 \%$ of DM; $P<0.001$ ), and $\triangle$ NDICP for these means differed from $0(P<$ $0.05)$. Other detectable contrasts for NDICP included a quadratic $(P=0.002)$ effect of sampling date, and greater concentrations of NDICP for surface compared with core (3.97 vs. $3.65 \%$ of DM; $P<0.001)$. Although we found detectable contrasts for ADICP, no treatment mean for $\triangle \mathrm{ADICP}$ differed from $0(P>0.05)$. Analysis of summative calculations of energy density yielded a linear $(P=0.001)$ increase of 1.3 percentage units across sampling dates, and a more energy dense forage in the bale core compared with surface (54.1 vs. $53.1 \%$ of DM; $P<0.001)$. The latter response is consistent with greater losses of WSC, as well as greater $\Delta$ values for most fiber components (Table 2) at the bale surface compared with core. Considered across all bales, the mean cost of fermentation and storage was 2.2 percentage units of TDN, which was slightly greater than reported previously (1.2 percentage units; Coblentz et al., 2016b) for similar forage preserved as baled silage.

\section{CONCLUSIONS}

Increasing the initial bale moisture from 36.1 (dry) to $47.5 \%$ (ideal) improved fermentation of alfalfa/mixed grass baled silages, resulting in a corresponding depression of $\mathrm{pH}$ from 6.00 to 5.52 . This was facilitated by increased production of lactic and total fermentation acids for ideal compared with dry baled silages. Overall, the cost of fermentation and storage for all bales in this study was a net loss of 2.2 TDN units, mostly occurring via losses of WSC via respiration. For bales of alfalfa/mixed grass silage wrapped with relatively minimal plastic (4 layers) and stored for extended time intervals lasting up to $357 \mathrm{~d}$, an OB had relatively little effect on silage fermentation or postensiled nutritive value compared with a commercial plastic wrap managed in an identical manner. Although positive benefits of OB have been demonstrated clearly in several previous experiments at other locations, these benefits were not observed in this experiment. However, this should not preclude continued investigations of potential benefits of OB technology, and under what conditions best results might be produced.

\section{ACKNOWLEDGMENTS}

Mention of trade names or commercial products in this article is solely for the purpose of providing specific information, and does not imply either recommendation or endorsement by the USDA. Research was supported in part by a generous grant (Agreement \#58-3655-2512) from Kuraray America Inc.

\section{REFERENCES}

AOAC International. 1998. Official Methods of Analysis, AOAC Official Method \#990.03. 16th ed., 4th rev. AOAC International, Gaithersburg, MD.

AOAC International. 2005. Official Methods of Analysis, AOAC Official Method \#995.21. 18th ed. AOAC International, Gaithersburg, MD.

Bolsen, K. K. 1995. Silage: basic principles. Pages 163-178 in The Science of Grassland Agriculture Forages. Vol. II. R. F. Barnes, D. A. Miller, and C. J. Nelson, ed. Iowa State University Press, Ames.

Borreani, G., and E. Tabacco. 2008. New oxygen barrier stretch film enhances quality of alfalfa wrapped silage. Agron. J. 100:942-948.

Borreani, G., and E. Tabacco. 2010. Use of new plastic stretch films with enhanced oxygen impermeability to wrap baled alfalfa silage. Trans. ASABE 53:635-641.

Coblentz, W. K., K. P. Coffey, and E. A. Chow. 2016a. Storage characteristics, nutritive value, and fermentation characteristics of alfalfa packaged in large-round bales and wrapped in stretch plastic film after extended time delays. J. Dairy Sci. 99:3497-3511.

Coblentz, W. K., and R. E. Muck. 2012. Effects of natural and simulated rainfall on indicators of ensilability and nutritive value for wilting alfalfa forages sampled before preservation as silage. J. Dairy Sci. 95:6635-6653.

Coblentz, W. K., R. E. Muck, M. A. Borchardt, S. K. Spencer, W. E. Jokela, M. G. Bertram, and K. P. Coffey. 2014. Effects of dairy slurry on silage fermentation characteristics and nutritive value of alfalfa. J. Dairy Sci. 97:7197-7211.

Coblentz, W. K., R. K. Ogden, M. S. Akins, and E. A. Chow. 2016 b. Storage characteristics, nutritive value, and fermentation characteristics of large, round bales of alfalfa-mixed grass forage wrapped with different layers of stretch film. Prof. Anim. Sci. 32:805-815.

Dubois, M., K. A. Gilles, J. K. Hamilton, P. A. Rebers, and F. Smith. 1956. Colorimetric method for determination of sugars and related substances. Anal. Chem. 28:350-356.

Hancock, D. W., and M. Collins. 2006. Forage preservation method influences alfalfa nutritive value and feeding characteristics. Crop Sci. 46:688-694

Huhnke, R. L., R. E. Muck, and M. E. Payton. 1997. Round bale silage storage losses of ryegrass and legume-grass forages. Appl. Eng. Agric. 13:451-457.

Jennings, J. A. 2011. Baled silage for livestock. \#FSA3051-PD4-11RV. University of Arkansas Cooperative Extension Service, Little Rock.

Keles, G., P. O'Kiely, J. J. Lenehan, and P. D. Forristal. 2009. Conservation characteristics of baled grass silages differing in duration of wilting, bale density, and number of layers of plastic stretch-film. Ir. J. Agric. Food Res. 48:21-34.

Keller, Th., H. Nonn, and H. Jeroch. 1998. The effect of sealing and of additives on the fermentation characteristics and mould and yeast counts in stretch film wrapped big-bale lucerne silage. Arch. Tierenahr. 51:63-75.

Kung, L., and R. Shaver. 2001. Interpretation and use of silage fermentation analysis reports. Focus on Forage. Vol. 3. No. 13. University of Wisconsin Extension and College of Agricultural and Life Sciences. Madison.

Mahanna, B., and L. E. Chase. 2003. Practical applications and solutions to silage problems. Pages $855-895$ in Silage Science and Technology. D. R. Buxton, R. E. Muck, and J. H. Harrison, ed. American Society of Agronomy, Crop Science Society of America, and Soil Science Society of America, Madison, WI.

McDonald, P., and R. A. Edwards. 1976. The influence of conservation methods on digestion and utilization of forages by ruminants. Proc. Nutr. Soc. 35:201-211. 
McDonald, P., A. R. Henderson, and S. J. E. Heron. 1991. The Biochemistry of Silage. 2nd ed. Chalcombe Publications, Marlow, Buckinghamshire, UK.

Muck, R. E., L. E. Moser, and R. E. Pitt. 2003. Postharvest factors affecting ensiling. Pages 251-304 in Silage Science and Technology. D. R. Buxton, R. E. Muck, and J. H. Harrison, ed. American Society of Agronomy, Crop Science Society of America, and Soil Science Society of America, Madison, WI.

Muck, R. E., and R. P. Walgenbach. 1985. Variations in alfalfa buffering capacity. ASAE Paper No. 85-1535. Am. Soc. Agric. Eng., St. Joseph, MI.

Müller, C. E., T. M. Pauly, and P. Udén. 2007. Storage of small bale silage and haylage - Influence of storage period on fermentation variables and microbial composition. Grass Forage Sci. 62:274-283.

Nicholson, J. W. G., R. E. McQueen, E. Charmley, and R. S. Bush. 1991. Forage conservation in round bales or silage: effect on ensiling characteristics and animal performance. Can. J. Anim. Sci. $71: 1167-1180$.

NRC. 2001. Nutrient Requirements of Dairy Cattle. 7th rev. ed. Natl. Acad. Press, Washington, DC.

Rotz, C. A., and R. E. Muck. 1994. Changes in forage quality during harvest and storage. Pages $828-868$ in Forage Quality, Evaluation, and Utilization. Proc. Natl. Conf. on Forage Quality, Evaluation, and Utilization, Lincoln, NE. 13-15 Apr. 1994. G. C. Fahey et al., ed. American Society of Agronomy, Crop Science Society of America, and Soil Science Society of America, Madison, WI.

Shinners, K. J. 2003. Engineering principles of silage harvesting management. Pages 361-404 in Silage Science and Technology. D. R Buxton, R. E. Muck, and J. H. Harrison, ed. American Society of Agronomy, Crop Science Society of America, and Soil Science Society of America, Madison, WI.

Shinners, K. J., B. M. Huenink, R. E. Muck, and K. A. Albrecht. 2009. Storage characteristics of large round and square alfalfa bales: lowmoisture wrapped bales. Trans. ASABE 52:401-407.

Weiss, W. P., H. R. Conrad, and N. R. Pierre. 1992. A theoreticallybased model for predicting total digestible nutrient values of forages and concentrates. Anim. Feed Sci. Technol. 39:95-110.

Wilkinson, J. M., and J. S. Fenlon. 2013. A meta-analysis comparing standard polyethylene and oxygen barrier film in terms of losses during storage and aerobic stability of silage. Grass Forage Sci. 69:385-392. 